\title{
Exploration of Training Innovative Talents in College English Teaching
}

\author{
Lili Luo \\ Shaanxi Institute of International Trade and Commerce, Xi'an, Shaanxi, 712046, China \\ yyabm2004@163.com
}

Keywords: English language innovative talents, Interdisciplinary, Overall Quality, Scientific Evaluation

\begin{abstract}
This article analyzes the measures taken and achievements made by normal universities in cultivating English language innovative talents, and the existing problems were summed up. Emphasis should be placed on the ability of subject application to reflect the practical value of foreign languages. From the practical aspects of foreign language, a learning concept of dedication was established, and professional disciplines effectively combined. Through research and analysis, we can fully understand the inherent social requirements of foreign language innovative talents. It can break the theoretical limitations of teaching foreign language teaching from the perspective of teaching thinking, enrich the knowledge system of foreign language majors, and adopt a method of joint development with applied disciplines.
\end{abstract}

\section{Introduction}

The connotation of English teaching innovative talents is that they have the ability of innovation in foreign language major. Foreign language innovative talents have a good foundation of foreign language and have a deep understanding and mastery of the cultural background knowledge ${ }^{1}$ They usually have a knowledge and skill system that includes a plurality of disciplines. It can integrate professional subject knowledge and foreign language knowledge with innovative thinking. And it can work with the traditional and innovative ways to deal with possible job problems, into the community after a strong competitive edge. ${ }^{2}$ Innovative English talents have the following salient features: solid foreign language knowledge and application skills, careful logical judgment, open way of thinking, and firm belief of success. ${ }^{3}$ The composition of the English knowledge system is not limited to the foreign language profession itself, but extends to many professions related to the application of foreign languages and has a sufficient level.

In addition to theoretical guidance, the cultivation of innovative talents must be combined with practical activities and undergo empirical tests and confirmations. ${ }^{4}$ The essence of innovative talents is to fully cultivate and improve the quality of educated students. The content of quality usually has psychological quality, physical quality, responsibility quality and innovative thinking quality. To grasp the social essence of innovative talents should correctly grasp the relationship between knowledge, ability and quality. The knowledge of innovative talents is to improve the comprehensive development of the educated's physical, psychological, social and creative qualities, which includes not only scientific knowledge but also humanistic knowledge. However, imparting knowledge is not unilateral. ${ }^{5}$ At the same time, it also cultivates students' knowledge, organizes the awareness of judgment and comprehensively improves the non-intellectual factors including emotional power, willpower and understanding.

Based on multidisciplinary theories and methods such as pedagogy, psychology and management, this paper studies the teaching ability of college English teachers and their ways to enhance the teaching ability through field research and empirical research analysis. Through further understanding of the composition of college English teachers teaching ability and its main problems, this study provides theoretical support and policy support for developing college English teachers' teaching ability. It improves teaching quality and promotes the healthy growth of college English teachers. 


\section{Research Content and Methods}

\section{Research Content}

The "college English teacher" in this research mainly refers to teachers engaged in specialized English teaching at College of Foreign Languages. The "teaching ability" in this paper refers to the specific ability in teaching, including the ability of teaching design, the ability of teaching implementation, the ability of academic examination and evaluation, the ability of teaching monitoring and reflection, and the ability of teaching and research. ${ }^{6}$ The main contents of this study include the following parts: First, summarize the status quo of college English teachers' teaching ability. Second, a general overview of non-agricultural colleges and universities is represented by normal universities.

\section{Research Methods}

Literature research method: Based on the teaching ability of college English teachers, it makes use of the book materials and electronic document retrieval system. A large number of relevant theoretical data at home and abroad were used. It fully grasps the research status of college English teachers teaching ability, to determine the college English components of teaching ability of teachers.

\section{Survey Results Analysis}

In order to better understand the effect of cultivating innovative talents in current foreign language institutes, the program of personnel training in foreign language institutes was carefully studied and questionnaires and surveys respectively between foreign language teachers and students was conducted. Students were also instructed to fill in the score sheets, teaching objectives, teaching content, teaching practice and evaluation system of teaching evaluation scores. In order to make the survey universal, authenticity, questionnaires and questionnaires were issued a total of 1000, mainly for English college, and the actual recovery is 990. Survey scores and feedback papers were collated and analyzed, the following system data analysis were made combined with these:



Figure 1. Survey results of teaching objective in English college.

As can be seen from Figure 1, among the existing teaching objectives of the faculty of foreign languages, reading comprehension, language skills, writing abilities and learning strategies of foreign languages are respectively 8.4, 7.2, 7.4 and 7.6. This shows that the current level of foreign language is quite high, and it can meet the learning needs of students. Students affirmed for the field of professional teaching ability, and self-literacy. The application of language skills and new learning concepts seem a bit poor, with only 6.3 and 6.7 points. On the one hand, it shows that students need more breadth of knowledge of other disciplines to enrich themselves and stimulate their ability of thinking and judgment of logic. They need the initiative thinking ability with personality to face fierce social competition. The questionnaire feedback also reflects English teaching has shortage in these two aspects of classroom teachin. It needs foreign language schools to make targeted investigations in the future teaching plan. Subjective evaluation of students also expressed the hope to increase the combination of foreign language and applied disciplines. 


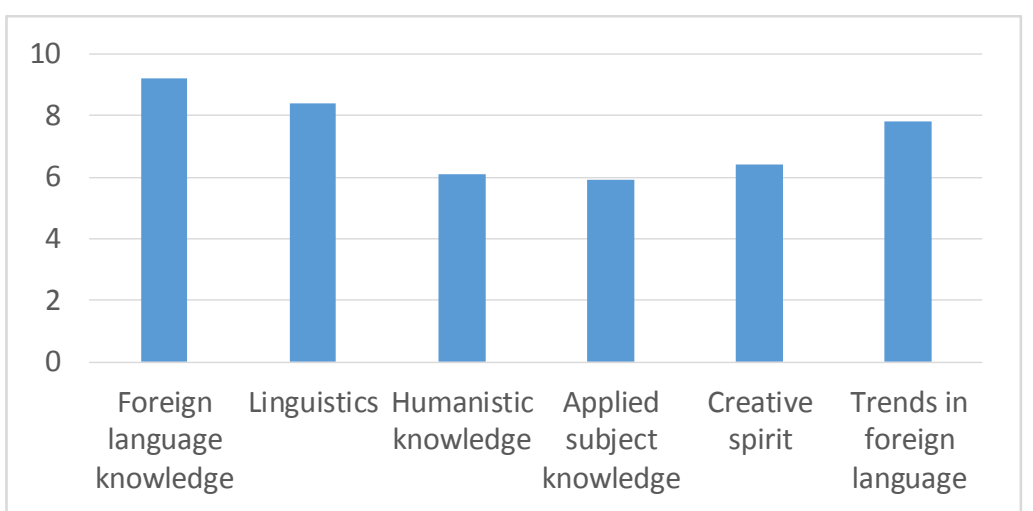

Figure 2. Survey results of teaching content in English college.

As shown in Figure 2, foreign language and linguistics make English students very satisfied with scores of 9.2 and 9.1 respectively. The humanities and foreign language development trend of teaching is still good, respectively, 7.3 and 7.6 points. This result is basically consistent with the feedback from the questionnaire. This shows that the normal university achieved results in foreign language teaching innovative talents, which gets the students recognition. Unfortunately, the application of subject knowledge and innovative spirit, which includes the individual learning awareness in English learning and the generation of self-awareness in foreign language-related fields of expertise, are unsatisfactory in understanding the importance of innovation, with only 6.2 and 6.1 respectively. Most students in the questionnaire are generally confused about innovation, they do not know what to do, how to do, and almost all have the same requirements of a professional teacher guidance. This shows that the existing teaching content is obviously lacking in this aspect. Teachers can not fully realize the teaching goal of cultivating foreign language innovative talents, and which needs to be supplemented by targeted investigations in the following teaching reform.

\section{Training Foreign Innovative Talents in Practice}

\section{Teaching Objectives}

We can believe that the essence of English teaching at this stage is to give students foreign language knowledge and grasp it. Only based on the premise of language application, English teaching is meaningful, and truly exerts the communicative effect of foreign language itself. We must improve the quality of foreign language students in all aspects and must overcome the limitations of existing foreign language disciplines. According to students' characteristics and learning content, teachers should use the interactive environment of network language, collaborative learning and practical resources, so that students can listen English news online. And it can cultivate independent understanding and expression ability of English training. Students can chat online and chat with foreign language users through online chat rooms. For example, teachers organize colorful extracurricular activities: let the students use the foreign language "charm" foreign language festival, and fully display their talent.

Enable students to establish a learning concept of learning. English teaching is not just the teaching of foreign language knowledge. From the perspective of the application of foreign languages, English learning is based on the application of science. The foreign language content to cover the subject content, to achieve the exchange of information between different language groups. Expand the amount and type of extracurricular reading materials for students.

\section{Teaching Content}

Teaching content is an important category of cultivating English teaching innovative talents. First of all, fully instill the spirit of innovation, and make it solidified in the subconscious teachers and students. Secondly, help to gradually develop the students' sense of innovation from many aspects of English teaching. At the same time, interdisciplinary content is added to the content of knowledge to enrich students' knowledge system.

In cultivating English teaching innovative talents, we must reflect the cultivation of innovative 
spirit. The spirit of innovation is an individual's ideological consciousness, which comes from the students' initiative on knowledge and the influence and restriction of people's subjective thinking ability. Active thinking is a direct source of innovation, and only students with active thinking skills are likely to spark their inspiration. Cultivation of students' initiative thinking ability starts from imitation. Learn to imitate the face of the problem analysis and the solution to the problem of ideas. Work ideas are to change the one-way transfer of knowledge from teachers to students teaching methods. Students in the teaching process should be regarded as equal to the subject, to give students participation in teaching organization opportunities. In order to activate the vitality of classroom teaching, stimulating students' creativity and making foreign language teaching become a truly impartial knowledge transfer cycle of imparting behavior.

\section{Summary}

The cultivation of English teaching innovative talents is a complicated systematic project. It requires college education administrators and foreign language teachers to take a long-term perspective and to understand and analyze the essence of the current social needs of foreign language professionals. It also requires to accurately grasp the core of foreign language professional innovation content. The training of foreign language innovative talents must have a strong teaching evaluation system for protection. First of all, a team of foreign language teachers who possess superb professional qualities and ideological qualities should be constructed. And second, employ recruitment and training to enrich schools. Teaching management department should be rewarded from the material and spiritual aspects of innovation and personnel training of individuals.

\section{References}

[1] Kurkgöz, Y., A case study of teachers' implementation of curriculum innovation in English language teaching in Turkish primary education. Teaching \& Teacher Education An International Journal of Research \& Studies. 2008, 24 (7): 1859-1875.

[2] Secada, W. G.; Others, A., Innovative Strategies for Teaching Mathematics to Limited English Proficient Students. Program Information Guide Series, Number 10, Summer 1989. Basic Skills. 1989, 26.

[3] Payne, J., Precollege science teachers need better training: U.S. science education is improving, but a few local programs are demonstrating how it can become even better. Issuesinscienceandtechnology. 2004, :21 (:1).

[4] Nagai, Y.; Lister, R., From Vernacular to English: A Model of Innovation from within the Hearts of the Indigenous Teachers in Papua New Guinea. Language \& Education. 2004, 18 (6): 525-538.

[5] Jerg, A.; Öchsner, W.; Wander, H.; Traue, H. C.; Jergbretzke, L., The FAMULATUR PLUS as an innovative approach for teaching physical examination skills. Gms Journal for Medical Education. 2016, 33 (1).

[6] Okoth, T. A., Challenges of Implementing a Top-Down Curriculum Innovation in English Language Teaching: Perspectives of Form Iii English Language Teachers in Kenya. Journal of Education \& Practice. 2016, 7. 